\title{
A Tribute to Carl Adolph von Basedow: To commemorate 150 years since his death
}

\author{
Leonidas H. Duntas
}

Endocrine Unit, Evgenidion Hospital, University of Athens, Medical School, Athens, Greece

“... 1832 erkrankte Herr M. ernstlich an einem Brechdurchfalle, will danach nicht wieder gesund geworden sein, sondern seitdem viel an allgemeiner Hitze des Blutes, starken Schweissen und anfangenden Brustbeklemmungen gelitten haben, wobei er sich leidenschaftlich Abkuehlung darin fand, die Brustbekleidung gegen kalten Regen, Wind und Schneegestoeber zu oeffnen. In den Carotiden war Saegegeraeusch hoer- und fuehlbar, er hatte ein bleiches buffiges Anlitz, hervorgetriebene Augen..., die Schilddruese war angeschwollen, der Koerper etwas abgemagert, drei- bis viermal taeglich eine unverdaute Leibesoeffnung, trotz dessen aber ein reger Appetit zugegen... Der schlief nun, da die Augen immer hervorgetreten waren, ganz mit offenen Augen, die Bulbi waren aber in jeder Beziehung an sich gesund... “

Carl Adolph von Basedow, Wochenschrift f.d. Gesamte Heilkunde, 1840

With this original description of a case of hyperthyroidism and exophthalmous, the German physician Carl Adolph von Basedow masterfully described a disorder characterized by a triad of hyperthyroidism, goiter and exophthalmous in a publication that included three cases ${ }^{1}$. The symptoms of intolerance to heat, profound sweating, diarrhea and weight loss in the presence of increased appetite are impressively out-

Address correspondence and requests for reprints to: Leonidas H. Duntas, M.D., Endocrine Unit, Evgenidion Hospital, Papadiamantopoulou Str. 20, 11528 Athens, Greece, Tel.: +210-6748878; e-mail: ledunt@otenet.gr Received 15-04-04, Revised 21-06-04, Accepted 25-06-04 lined by the author, thus enriching the clinical picture of the disease that may also include cardiac arrhythmias, apprehension, weakness, tremor, elevated basal metabolism rate and psychotic alterations. In fact, some of these symptoms had previously been reported by the Irish physician Robert James Graves in $1835^{2}$, the Italians Antonio Giuseppe Testa in $1810^{3}$ and Giuseppe Flajani in $1802^{4}$ and by the British Caleb Hilier Parry who was the first to write an account of the disease in his unpublished writings in $1825^{5}$.

C.A. von Basedow was born in 1799 in Dessau, son of an aristocratic family. His grandfather was Johann Bernhard Basedow, a famous pedagogue of his time. He studied Medicine at the University of Halle, in the state of Sachsen-Anhalt, and trained in Paris for two years ${ }^{6}$. In 1822, he settled in Merseburg, a small town near Halle/Leipzig, where he practised as a general physician. He was exceptionally observant and worked skillfully in many branches of Medicine, frequently publishing his observations and post-mortem findings on various diseases. His historical contribution to thyroidology appeared in the distinguished medical journal of the time Heilkunde fuer die Gesamte Medizin on 28 March 1840, by coincidence the anniversary of the birth of the Irish physician Robert Graves, as a work entitled "Exophthalmos due to hypertrophy of the cellular tissue in the orbit"1. Thereafter, the cardinal symptoms - exophthalmous, goiter and tachycardia - characterizing the disease, became known as the triad of Merseburg. Since 1858 Basedow's disease has been the most commonly used term on the European continent, while Grave's disease is more widely used in the English speaking world. 
Carl Adolph von Basedow died on 11 April 1854 at the age of only 55 years. He had been infected in the post-mortem room while examining a patient who had died of typhus and succumbed a few days later to septicemia.

It is now well accepted that Basedow's disease is an organ-specific autoimmune process that differs from all other autoimmune diseases in being associated with target organ hyperfunction and not organ destruction ${ }^{7}$. Nevertheless, despite the considerable progress made over the last two decades, its etiology still remains controversial. Genetic research has shown that is most probably transmitted in a multifactorial way, with environmental factors also playing an important role in the genesis of the disease.

In conclusion, even 150 years after the death of its describer, the exact etiology of the triad remains enigmatic. However, it is the clinical description of the disease by the analytical intellect of Dr. C.A. Basedow that constitutes the essential basis for the hopefully imminent resolution of the puzzle of the triad of Merseburg.

\section{REFERENCES}

1. von Basedow CA, 1840 Exophthalmus durch Hypertrophie des Zellgewebes in der Augenhoehle. Wochenschrift fuer die Gesamte Heilkunde 13: 197-204; 220-228.

2. Graves RJ, 1835 New observed affection of the thyroid gland in females. London medical and Surgical Journal 7: 516-517.

3. Testa AG, 1810 Delle malattie del cuore, loro cagioni, specie, segni e cura. Bologna, $2^{\text {nd }}$ edition in 3 volumes.

4. Flajani G, 1802 Sopra un tumor freddo nell'anterior parte del collo broncocele (Osservazione LXVII). Collezione d'osservazioni e reflessioni di chirurgia, Rome, Milano, A Ripa Presso Lino Contedini 3: 270-273.

5. Parry CH 1825 Enlargement of the thyroid gland in connection with enlargement or palpitations of the heart. In: Collections from the unpublished medical writings of $\mathrm{H}$. Parry, London; pp, 111-129.

6. Meng W, 1999 Carl Adolph von Basedow - on the $200^{\text {th }}$ anniversary of his birth. Z Arztl Fortbild Qualitatssich 93: Suppl 1: 5-10.

7. Chen CR, Pichurin P, Nagayama Y, Latrofa F, Rapoport B, McLachlan SM, 2003 The thyrotropin receptor autoantigen in Graves disease is the culprit as well as the victim. J Clin Invest 111: 1897-1904. 